\title{
Proofs and Refutations
}

\section{IMRE LAKATOS}

\section{Edited by E. ZAHAR and J. WORRALL}

An original and novel introduction to the philosophy of mathematics. Much of the book takes the form of a discussion between a teacher and a group of students; they investigate various problems in the history and philosophy of mathematics, and consider the interplay between them.

Hard covers $£ 7.50$ net Paperback $\mathbf{1 1 . 9 5}$ net

\section{Method and Appraisal in the Physical Sciences}

The Critical Background to Modern Science 1800-1895

\section{Edited by COLIN HOWSON}

A volume of studies on the problem of theory-appraisal in the physical sciences-how and why important theories are developed, changed and are replaced, and by what criteria we judge one theory an advance on another.

$£ 10.50$ net

\section{Method and Appraisal in Economics}

\section{Edited by S. J. LATSIS}

The central problem of the essays in this volume is the problem of theory appraisal in economics.

\$7.50 net

\section{Teleology}

\section{ANDREW WOODFIELD}

The notions of purpose, goal, end and function are used (and abused) in descriptions of a very wide range of human, animal and machine behaviour. Andrew Woodfield provides here a unified account of such teleological descriptions and explanations, their varieties, their logical structure and their proper uses.

\&6.50 net

\section{CAMBRIDGE UNIVERSITY PRESS}




\section{The Correspondence of John Locke}

Volumes I and II

Edited by E. S. De Beer

John Locke's letters constitute the principal authority for his biography, especially as they show his material, intellectual, and spiritual environment. They bring together the ordinary course of his life and many of the great issues of his time. This edition will be published in eight volumes: the letters are printed from the original manuscripts wherever possible, and arranged chronologically. These two volumes cover the years 1650-1686. $£ 25$ each

\section{Kant's Critique of Pure Reason}

A Commentary for Students

T. E. Wilkerson

This commentary is a detailed and systematic examination of the first Critique designed for students of philosophy in their second and third year and anyone else approaching Kant for the first time. The author explains Kant's elaborate technical terms and rhetorical idiosyncrasies, and relates his work to that of the great rationalist and empiricist philosophers and to modern epistemology. £6 paper covers $£ 2.50$

\section{Plato: Protagoras}

\section{Translated with notes by C. C. W. Taylor}

The Protagoras vividly depicts the clash of traditional Greek values with Sophistic and Socratic teaching, and deals with many central themes in Platonic ethics, particularly the nature of human goodness and its relation to knowledge and to pleasure. The translation aims at accuracy and attention to detail, and the notes at full critical discussion of the arguments and explanations of the usage of significant terms. $£ 7.50$ paper covers $£ 3.75$ Clarendon Plato Series

\section{Social Thought in America}

The Revolt Against Formalism

\section{Morton White}

'Professor White's book is an essay on the history of social ideas in America from the end of the nineteenth to the 30s of the twentieth century ... an exceptionally lucid, penetrating, and just account of a social and intellectual movement.' Isaiah Berlin. Paper covers $£ 2.50$ Galaxy Books

\section{Oxford University Press}


Two new titles in the Library of Philosophy and Religion

\section{THE AVAILABILITY OF RELIGIOUS IDEAS}

\section{Ramchandra Gandhi}

Mahatma Gandhi's grandson here explores philosophically what it is to be a conscious person in community, and shows how the religious ideas of the soul, of God, prayer, immortality, the mystical and miraculous are generated by a kind of moral necessity out of our basic responsibility towards one another. Hence the title-the availability of religious ideas even to the humanist, who stands outside all established religious traditions.

£7.95

\section{THE USE AND ABUSE OF THE BIBLE}

\section{Dennis Nineham}

The basic concern of this book is the wide disparity between present Western culture and the context of beliefs held by those who wrote the Bible and who have interpreted it during the greater part of Christian history. How, therefore can our present culture understand the Bible?

$£ 10.00$

For further details, please write to Anne Calcott (P), The Macmillan Press, Little Essex Street, London WC2R 3LF 


\section{Oxford Journals}

\section{The British Journal of Aesthetics}

\section{Volume 16 No. 3 Summer 1976}

\section{Contents}

Art, Imagination and Mr. Scruton David Pole

Organic Unity Again Harold Osborne

The Importance of Hume in the History of Western Aesthetics Mary Carman Rose

Aestheties, Morals and Max Scheler's Non-Formal Values Peter H. Spader

The State and Civil Society as Objects of Aesthetic Appreciation R. T. Allen

Ways of Abstraction Harold Osborne

Aesthetic Theory and Hindustanj Rhythm S. K. Saxena

The Influence Argument $R$. Humphris

The Three Paradoxes of the Photograph Philip Crick

Pictorial Styles in the Art of Children Rita Simon

Book Reviews

Books Received

The British Society of Aesthetics

To place an order or obtain an inspection copy please write to:

Journals Manager, Oxford University Press, Press Road, Neasden, London NW10 0DD

\section{Oxford University Press}

Volume LXXXIV

\section{MIND-OCTOBER 1976}

Edited by D. W. HAMLYN

Articles:

Identity and Personal Identity: E. J. BorowsKI

On What Sorts of Thing There Are: L. STEvenson

The Objectivity of Pain: N. FLEMING

Spinoza on the Mind-Body Problem: Two Questions: C. B. DanIELS

Wiggins on Identity: H. W. NOONAN

Discussions:

Space and Time Re-assimilated: B. MAYO

Sophist 263B Revisited: K. M. SAYRE

Negative Utilitarianism: Not Dead Yet: R. I. SIKora

The Prescriptivism Incompleteness Theorem: H. J. GENSLER

The Identity of Laws: A Reply to Mr Griffin: R. Harré

A Note on Belief: D. M. JohNson

Critical Notice:

The Central Questions of Philosophy by A. J. Ayer: J. Harrison

Book Reviews

Books Received

Published for the MIND ASSOCIATION by BASIL BLACKWELL

Single issues: $\mathfrak{£ 1 . 2 5}$

Annual Subscription: $\mathfrak{£ 4 . 0 0}$ 